\title{
Guided Paper: Water Accounting Reporting System -WARS Framework from Concept to Implementation for Sustainable Water Management
}

\author{
Amgad Elmahdi* \\ Head of MENA Region, International Water Management Institute-IWMI, Egypt
}

Submission: February 06, 2020; Published: February 18, 2020

*Corresponding author: Amgad Elmahdi, Head of MENA Region, International Water Management Institute-IWMI, Egypt

\begin{abstract}
Four years since the adoption of the Sustainable Development Goals, UN-Water reports show the world is off track to achieve the water goal - the heart of the SDGs-, thus the same goes for all water related SDGs (only 10 years to harvest SDGs). Amid lots of highlights on what we need to do, governments must decide how to incorporate SDG 6 targets into national planning processes, policies and strategies and set their own targets, taking into account local circumstances and contexts including cultural. The SDGs anticipate substantial improvements in the efficiency, productivity and sustainability of water use; safe treatment and reuse of wastewater; integrated approaches to water management; and, the resilient food production systems. When well-adapted and well-implemented, water accounting provides countries and/or regions that face increasing water scarcity a sound and transparent basis for managing the scarce water resources and take actions to achieve relevant SDGs and other targets including evaluating water resources plan and developments.
\end{abstract}

However, Water accounting system needs to be tailored, integrated, detailed, and standardized. Accurate water accounting is vital for understanding hydrological processes, managing water flows and informed dialogue about water and future planning. For this reason, various organizations, including Food and Agriculture Organization of the United Nations (FAO), other UN agencies, IHE Delft, IWMI and WWC have joined forces to develop standard frameworks for water accounting. However, there is a gap in understanding their implementation and use for what purpose including consisting reporting system. This paper is discussing the challenges in designing a water accounting system that fit for purpose at the country level or at any other spatial scales, that might require the use of one or many of these water accounting's frameworks by itself or in combination with other tools such as modelling, remote sensing, data analysis, etc. It will attempt to provide a consensus understanding of water accounting reporting system-WARS for sustainable water use and management, policy development and informing water debates. This water accounting reporting system-WARS framework will facilitate the water accounting system design and development at the country level. The paper will also provide insight on how to establish a water accounting team in the country to facilitate the process of WARS.

Keywords: Water management; Sustainable development goals; Institutionalized; Hydrology; Hydrogeology; Economy; Environment; Social

\section{Introduction}

The SDGs are not just a global reporting exercise, but rather involve a global program that holds country-led national efforts and actions [1]. For centuries, the control and delivery of water without the appropriate institutional framework has changed states and economies across the Middle East and North Africa (MENA) region. In the 20th century, infrastructure development tamed key river systems and led to huge expansion in irrigation, while population nearly quadrupled. Despite important advances in water management, MENA region is thus becoming a hotspot of challenges posed by goals of sustainable water use. The SDGs anticipate substantial improvements in the efficiency, productivity and sustainability of water use; safe treatment and reuse of wastewater; integrated approaches to water management; and, the resilient food production systems that is essential for the MENA region's future [2].

Global, regional and local expertise shows that innovative technical and business solutions in combination with "Water Accounting" can result in improved water management and water security, which is central for rapid progress toward the Sustainable Development Goals (SDGs) (Amgad Elmahdi 2018) [3-6]. Upscaling of these solutions requires major changes in water policy and practice supported by appropriate new instruments like Water Accounting. Water Accounting (WA) is a relatively new concept and tool developed to bridge the world of 
natural water resources management and productive water use. Water accounting mimics the financial accounting in its principles and seeks to provide comprehensive, consistent and comparable information related to water for policy- and decision-making to promote a sustainable use of water resources as well as equitable and transparent water governance among water users.

Accurate water accounting is vital for understanding hydrological processes, managing water flows and informed dialogue about water and future planning. For this reason, various organizations, including Food and Agriculture Organization of the United Nations (FAO), other UN agencies, IHE Delft, IWMI and WWC have joined forces to develop standard frameworks for water accounting [7]. However, these actions produced different frameworks that are mainly based on two approaches:

a) Flow accounting methods (FAO's Aquastat, UN's SEEWater, and Australian Water Accounting) and

b) Depletion accounting methods (ICID, IWMI-WA and joined force by IHE, IWMI and FAO for WA+).

The principles behind these two approaches are, flow accounting is using more measured data while the second (depletion accounting) is tracking water depletions (consumptive use of water) rather than withdrawals using remote sensing techniques. However, implementation and adoption of any of these frameworks are hindered by lacking the institutional framework and a clear roadmap to develop water accounting system that is tailored to the case (basin, region, country, etc). These can maximize the benefits of implementing water accounting for sustainable water management that can dealing with the many actors in the water sectors, filling the gap in water information in relation to water management and realize the polarization in the water sector in relation to water allocation and addresses the relation between soft and hard institutions. These two hindered factors were answered [8] by proposing the roadmap to designing a tailored water accounting system at the country level and providing institutional framework (to support the institutionalization of the water accounting).

It is notable, implementation of any of these frameworks or water accounting approaches also require understanding of their purpose and how they can fit in the water accounting system that meet the country needs within the water accounting reporting framework. This paper is providing a water accounting-reporting system-WARS that positioning all these frameworks in the context of how to develop water accounting system and for what purpose at multi-scalar level from field, scheme, district, basin and national considering administrative and hydrological boundaries and their overlapping in most of the cases. When water accounting is well-adapted, designed and implemented, it provides countries and/or regions that face increasing water scarcity a sound and transparent basis for managing the scarce water resources and take actions to achieve relevant SDGs and other targets including evaluating water resources plan and developments

\section{Water Accounting}

The concept of Water accounting is not new and it was debatable, early in the 80s, there was a demand for green accounts by the French government that led to the first effort to propose a water accounting framework both physical and financial water accounting [9]. This followed by piloting in early 90 s by Spain and France, however, did not developed further [3]. The UN Economic and Social division built on that framework to develop SEEAW that was published in 2012. In the meantime, the Australian government announced the water act 2007 and mandated the national water accounting (BOM, 2010). It can be noted, from its implementation and adoptions, it is nearly a new concept.

Water accounting can be commonly defined as it is a systematic study of the hydrological cycle and the current status and future trends in both water supply and demand. Beyond the simple accounting of volumes and flows, it also focuses on issues relating to accessibility, uncertainty and governance of water. Therefore, Water Accounting is a critical tool to support any initiative aiming at addressing the challenges of water scarcity [10]. Various organizations, including Food and Agriculture Organization of the United Nations (FAO), other UN agencies, Bureau of MeteorologyAustralia, IHE Delft, IWMI and WWC have joined forces to develop standard frameworks for water accounting [7]. These frameworks are fit for different purposes and are using different assumptions, tools, approaches and data requirements [11]. Table 1, presents an overarching comparison of these frameworks to serve as simple guide to inform the choice of the framework that can meet the needs of the country.

A well designed and institutionalized water accounting system requires:

a) Systems and/or platforms for acquiring and managing data and information.

b) A range of methods, models and tools for processing,

c) Analyzing and interpreting of outputs.

d) A specialized team with relevant knowledge and experience (hydrology, hydrogeology, economy, environment, social, GIS, etc) who are located in the same office or working at different institutional levels in different regions of a country.

e) Active engagement with key stakeholders and users who may share data and/or use water accounting outputs; and,

f) Enabling institutional environment (soft and hard) for mandates and accountability.

Applying these frameworks will benefits to empower the water managers, user and the country to develop a tailored water accounting system, reporting on SDGs, and sustainably manage 
their water resources. Investments are really needed at the country level to be able to develop their tailored water accounting. Therefore, for any country to start that investment, there is a need to understand where all these frameworks are positioned within the context of water accounting reporting.

Table 1:

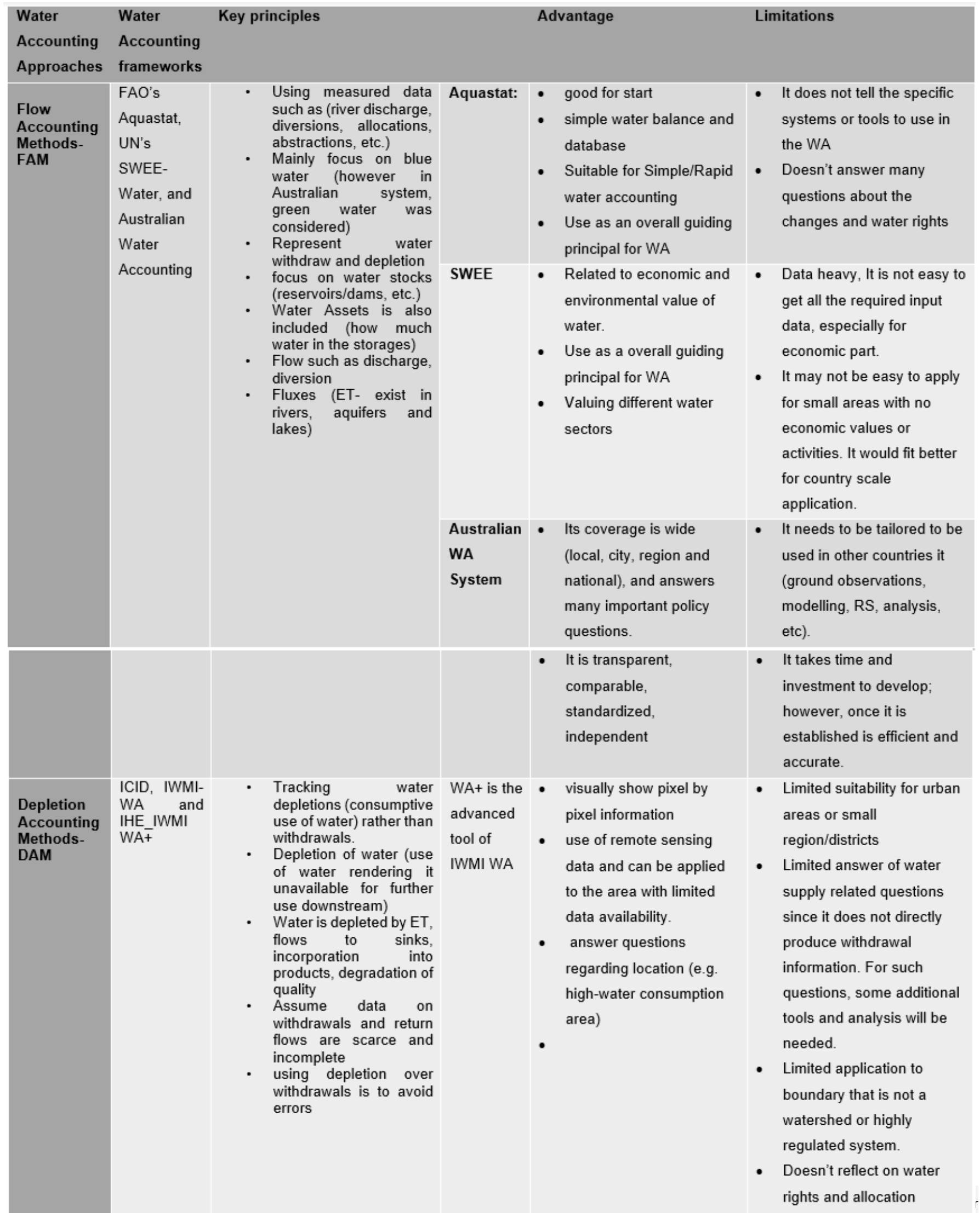




\section{Desirable attributes of water accounting systems}

Some water accounting systems are standardized to the point that one size fits all. However, most water accounting systems can be tailored to meet the priority demands and needs of a country or a region. Arguably, to design a water accounting system, it needs to be:

a) Standardized in terms of its procedures, principles, concepts and terminology.

b) Tailored to the availability of relevant remotely sensed and terrestrial information.

c) Tailored to the needs, priorities and scales of most interest to potential users of water accounting outputs.

d) Take a multi-scalar approach or nested structure system that typically involves analysis and modelling at three or more scales or institutional levels.

e) Take explicit account of uncertainty and ensure that levels of uncertainty in outputs are communicated along with relevant outputs.

f) Communicate outputs in forms and formats that meet the requirements of decision makers

g) Make good use of secondary information and open access database.

h) Make good use of advances in informatics and cybertechnologies e.g. interactive visualizations and dashboards, web-based applications etc.

i) Make good use of advances in data acquisition methods / tools and have dynamic links to databases, web-based environmental sensors etc.

\section{Challenges of operationalizing and institutionalizing WA}

Without doubt, operationalizing and institutionalizing water accounting is a challenging process that takes time and need collective actions from all stakeholders with a clear champion for the process and implementation [12]. There are number of lessons learns reported in the literature [2].

\section{In summary:}

a) Data availability, sharing, accessibility and gaps: In MENA region, data sharing is one of the key hinder factors. There is still unwillingness amongst key stakeholders to share data where data is treated as treasure and provide level of job security and, in some cases, hydrometric networks are poorly maintained and not oriented to collecting data on return flows. Unwillingness to share data is difficult to address, however it can be facilitated in the process of water auditing and accessibility of global remote sensing data. In contrast, there are many opportunities for improving hydrometric networks using, for example, new (and cheaper) web-based based sensors and communication systems. Indeed, at present, insufficient and lack of accessibility of the data are the biggest limitations to meaningful water accounting, and therefore understanding of their water-related risks and impacts. These limitations are:

Inadequate databases

Lack of access to data

Insufficient granularity of data

Data collection and monitoring

Data accuracy and uncertainty

Lack of regulation for data sharing

Data ownership

b) Team skills: In the MENA region, water-related government ministries and departments are well-endowed with engineers. Engineers are needed in water accounting teams, but not only them. An effective and meaningful water accounting requires specialist with knowledge and experience in hydrology/ hydrogeology, meteorology, agronomy, informatics, cyber technology, GIS and remotes sensing, economics, stakeholder engagement, communication etc

c) Operational and investment strategy: Water accounting is being piloted in a number of countries without further commitments as it is requires an operational strategy that accompanied with investment strategy to get the right skills, acquiring the right data (monitoring) and tailor tools or system. MENA's region GDP is the most impacted by water scarcity $70 \%$ in comparison to $24 \%$ world, this should encourage governments to investment in operationalizing water accounting. However, government departments in the MENA region have limited human capacity and financial resources to institutionalize comprehensive water accounting systems that operate at multiple scales and institutional levels. As a result, problem and/ or opportunity focused water accounting has been recommended that concentrates resources on acquiring and analyzing data related to priority issues or needs and scales of most interest.

d) Preparedness of water managers: As in other regions of the world, decision-making based on intuition and repetition of earlier decisions is common among the MENA region's water and irrigation sectors. A key challenge is therefore to shift to decision making that is well informed by facts and evidence produced and scrutinized water accounting and auditing processes. Outputs from water accounting are subject to high levels of uncertainties. The level increases when the input data are "uncertain" (gaps in data sets, badly functioning monitoring instruments etc.). Some of this uncertainty is essentially irreducible. Reducible uncertainty is best addressed by cycles of targeted learning aimed at improving 
the confidence in water accounting outputs. Uncertainty increases when the scale of the water accounting does not match the scale of the needed information (e.g., Basin scale water accounting may not provide good information on water supply, demand, and infrastructure on small/local scale).Water managers, need to accept numbers with uncertainty boundary and be able to make decisions.

e) Misconception of Whole system water accounting: To date, water accounting pilots in the many countries have focused mainly on trials and errors of applying one of water accounting frameworks by junior staff. Lack of understanding of the water accounting frameworks and its capacity, purpose and outputs, left the senior manager to call it system that can do everything and replace other system such as operational river system. This is a misconception that need to be revert and build the capacity of senior managers on what is water accounting and what can do and what is water accounting system means or involve (many elements as described in WARS).

\section{Water accounting reporting system-WARS}

Water Accounting Reporting System-WARS is a systematic way to bring all elements together to provide consensus understanding on data, tools, analysis, outputs, reports and key questions answered by the account. It facilitates the discussion between all stakeholders in the design, development and implementation phases according to their case and scale. It can also help in defining the role and power for each partner or stakeholders in operationalizing and institutionalizing the water accounting and how the information produced are suitable to who (technical, professional, managers and public). Figure 1 shows the key elements in the WARS. These elements are water

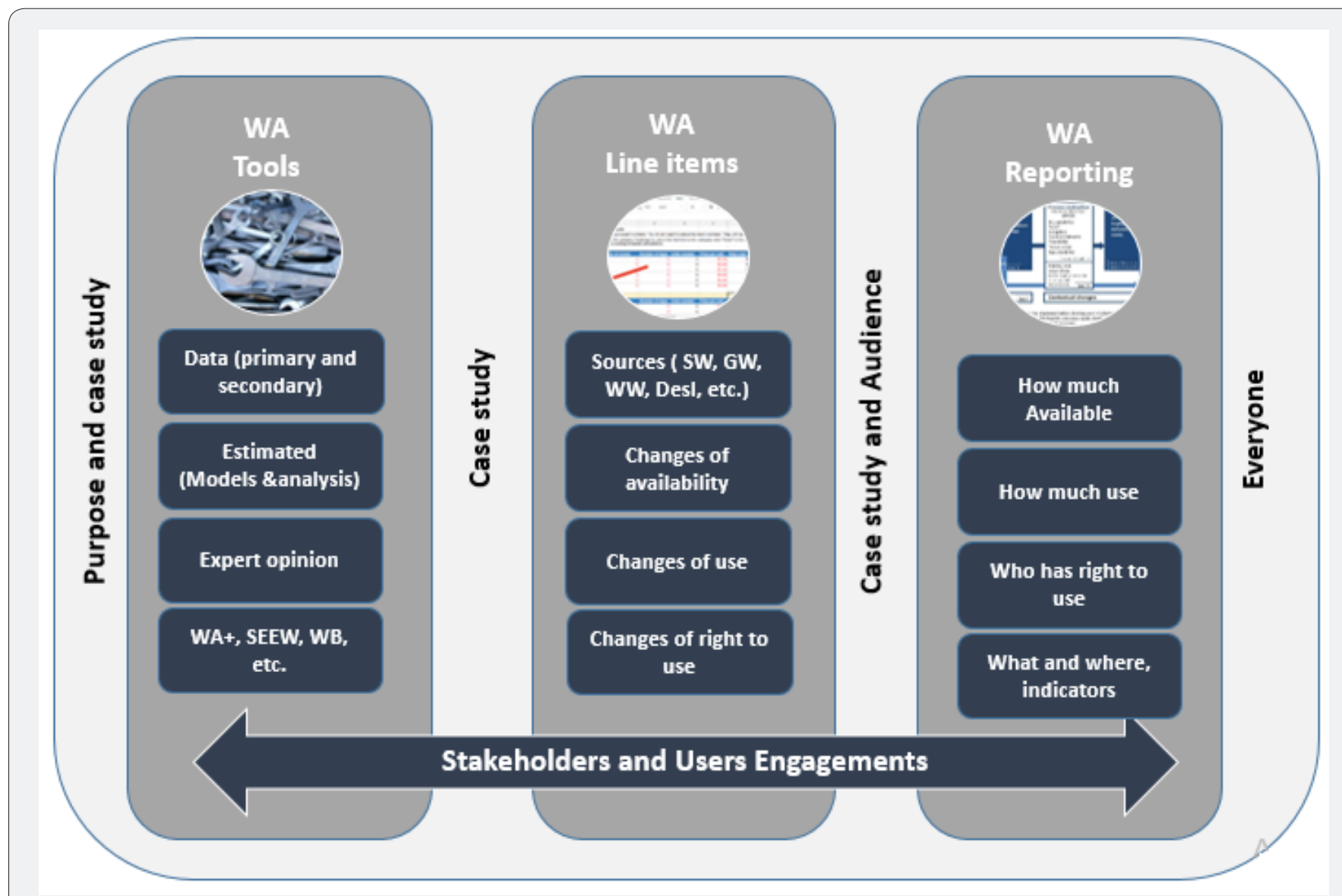

Figure 1: Water Accounting Reporting System- WARS elements.

a) Accounting tools,

b) Water accounting outputs/line items and

c) Water accounting reporting.

WARS conceptualize all these three elements and their inter-relation. WARS, starting by presenting the problem and defining the purpose of the water accounting from the country's perspectives that could water allocation between sectors. This is the first step before looking at the water accounting tools that could involve many components to design water accounting system. These components are 
a) Data that could be primary/measured data or secondary data (reports and other database),

b) Estimated data through analysis (water balance, trend, etc) and models (existing or new according to the case),

c) Expert opinion where data or model are not available,

d) Supporting tools for water accounting such as WA+ (where there is limited data), SEEW (where the focus on economic and environmental values), etc.

The second element of WARS is Water accounting outputs/ line items (adopting financial terms). It is focus on the case study and its boundaries as administrative, hydrological, combined in relation to the purpose, or questions in interests. This element represented

a) The water system components by water sources (surface water, groundwater, desalination, wastewater, etc, according to the case (irrigation or urban or basin for example)

b) The change in water availability such as rainfall, recharge, transfer, return flow, etc

c) The change in water abstraction/use by source and use

d) The change of rights or allocation or use.

The third element is water accounting reporting, that transfer water accounting outputs into a structure consistent report to communicate the water accounting outputs to wider audiences. The report needs to cover these main components:

a) How much water available and its status?

b) How much water used and its status?

c) Who has the right to use and existing regulations?

d) What and where indicators that related to value of the water accounting such as water productivity by system or region, etc

WARS presented a reporting system with clear processes however these processes are interconnected with feedbacks loop through stakeholders and users engagements. The processes of implementation of the WARS need to be owned and derived by specialist team (water accounting team). The structure of this team has to enabling itself to serve and deliver these processes to produce a meaningful water accounting report and outcomes. The commitment to establishing a water accounting team with the mandates to develop water accounting is require investment from the country to empower the team and also address some of the challenges that encountering in operationalizing and institutionalizing water accounting. The following section discussing the proposed structure of the team and its function.

\section{Water accounting team}

The structure of the water accounting team/unit has four key elements: Institutions, System, Data and Team [8]. The author discussed each component briefly. In this section, the paper is drill into the team component that provide the human resources that produce the account and validate its inputs and outputs. The paper proposing to structure the team into two groups: Analysts and Producers. These Analysts and Producers need to be setting and working together closely but also in close collaboration and communication with other stakeholders to the extension they can be setting physically at their premises or in ideal world, each stakeholder will have its small team to support water accounting activities where all form the team at the national level.

The roles of both Producers and Analysts are very complementary and each group is not strong without the other group. Each group provide specific skills and functions to the team. For example, producers provide the key technical skills required producing the water accounting; whiling, Analysts provide the key insights and analysis functions to the inputs and outputs of the water accounting to support the production of the water accounting report.

The key roles of the team/unit of water accounting is to support the sustainable water resources management, distribution and allocation and supporting the water resources policy, planning, development and monitoring; provide strategic technical services for investigations, studies, and special projects; and serve as the technical water resources information Centre at the country level. This is needs be clear in their mandates to provide systematic, regular, authoritative, standardized, and comparable water information to serve the national objectives and priorities.

Table 2: Water Accounting Unit/team functions.

\begin{tabular}{|c|c|c|}
\hline Data & Processes & Disseminations \\
\hline $\begin{array}{c}\text { Coordinate data collections and accessibility from } \\
\text { other government agencies and departments and } \\
\text { other water users including private sectors and } \\
\text { other related sectors }\end{array}$ & $\begin{array}{c}\text { Employs competent "water and other profession- } \\
\text { als" who are innovative, resourceful, collabora- } \\
\text { tive, and helpful in facilitating the management } \\
\text { and accountability of the water resources } \\
\text { management }\end{array}$ & $\begin{array}{c}\text { Publish an annual or seasonal water } \\
\text { account or as required and recommended } \\
\text { more frequently }\end{array}$ \\
\hline \multirow[t]{2}{*}{$\begin{array}{l}\text { provide water resources in a standard context, } \\
\text { using clear terminology and a standard data col- } \\
\text { lection system with known quality standards that } \\
\text { should be published in the report to establish the } \\
\text { confidence in each number }\end{array}$} & $\begin{array}{l}\text { Transform the information collected, analyzed } \\
\text { and published in water accounting into policy } \\
\text { briefs to inform water policy and plan develop- } \\
\text { ments }\end{array}$ & $\begin{array}{l}\text { Dissemination of water accounting results } \\
\text { to all stakeholders using the right platform } \\
\text { for each group of users }\end{array}$ \\
\hline & & $\begin{array}{l}\text { Liaison with all stakeholders on regular } \\
\text { basis to define their needs of using the } \\
\text { water accounting and secure their support. }\end{array}$ \\
\hline
\end{tabular}


To serve these roles and country's objectives and priorities, the unit/team need to apply these functions under each step (Table 2).

\section{Producers and Analysts}

Both roles of producers and analysts are the roles of both Producers and Analysts are very balancing and harmonizing (see
Figure 2). Without doubt, both roles are supporting each other and there is a joined function. These joined functions including

a) Discuss and decide on the temporal and spatial boundaries of the water accounting targeting region.

b) Discuss the key components of the regions.

c) Identifying the key data required and its sources.

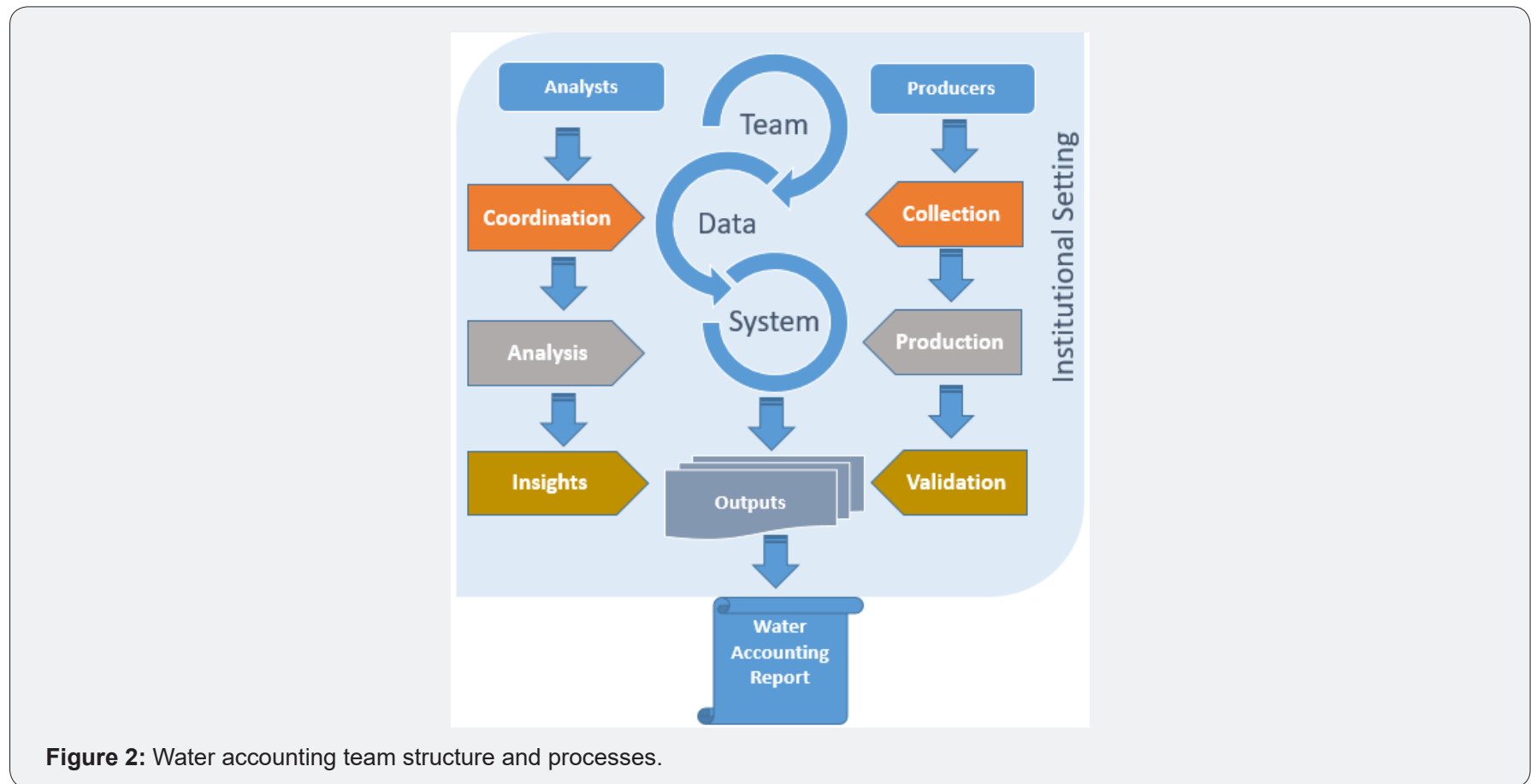

d) Agreed on the reporting structure to represent the key component of the targeting region.

e) Discuss the best methods to estimates water accounting components and fluxes.

f) Discuss the results of WA and how to improve it.
Specific roles and functions are also setting for performance by each group of producers and analysts. Producer's functions are setting along four key functions (collection, production, validation and dissemination) (Table 3). While, Analysts' functions are setting along three key functions (coordination, analysis, insights) (Table 4). These functions by producers and analysts need to be supported by the institutional settings [12-14].

Table 3: Producers' functions.

\begin{tabular}{|c|c|c|}
\hline Collection & Analysis & Validation \\
\hline $\begin{array}{l}\text { Collect and acquire data from its sources } \\
\text { including Analysts and other reporting part- } \\
\text { ners (external to the key ministry) }\end{array}$ & $\begin{array}{l}\text { Acquire technical capabilities with water accounting } \\
\text { systems, tools and techniques in depth }\end{array}$ & $\begin{array}{l}\text { Identify the sources of uncertainty and per- } \\
\text { form uncertainty analysis }\end{array}$ \\
\hline \multirow[t]{3}{*}{$\begin{array}{l}\text { Liaison with all stakeholders on regular } \\
\text { basis to define their needs of using the water } \\
\text { accounting and secure their support. }\end{array}$} & $\begin{array}{l}\text { Simulate all inputs through the WA systems to } \\
\text { produce outputs }\end{array}$ & $\begin{array}{c}\text { Validate water accounting numbers that been } \\
\text { simulated or estimated against a benchmark- } \\
\text { ing dataset }\end{array}$ \\
\hline & $\begin{array}{l}\text { Convert inputs from data providers into outputs } \\
\text { (water accounting balance reports) that Analysts } \\
\text { and other users can use and interpret. }\end{array}$ & \\
\hline & Analyse all outputs and discuss them with Analysts & \\
\hline
\end{tabular}


Table 4: Analysts' functions.

\begin{tabular}{|c|c|c|}
\hline Coordination & Analysis & Insights \\
\hline $\begin{array}{l}\text { Facilitate data collections and acces- } \\
\text { sibility }\end{array}$ & $\begin{array}{l}\text { Employs technical competent and provide help in } \\
\text { facilitating the management and accountability of the } \\
\text { water resources information provided by Producers. }\end{array}$ & $\begin{array}{l}\text { Provide data quality assurance and control in } \\
\text { particular to data received from other government } \\
\text { departments and water users including private } \\
\text { sector and other sectors }\end{array}$ \\
\hline \multirow[t]{2}{*}{$\begin{array}{l}\text { Liaise between high decision making } \\
\text { and Producers on practical and stra- } \\
\text { tegic water management issues }\end{array}$} & $\begin{array}{l}\text { Establish water resources standard that provide a } \\
\text { standard context and terminology in collection and } \\
\text { presenting data }\end{array}$ & $\begin{array}{l}\text { Review and approve policy brief draft before pre- } \\
\text { senting to senior managers and decision makers. }\end{array}$ \\
\hline & $\begin{array}{c}\text { Review and approve water accounting items and } \\
\text { outputs for publication }\end{array}$ & \\
\hline
\end{tabular}

\section{Conclusion}

Water accounting mechanism has received great attentions over the last decade by many donors and countries, where they are working hand in hand to adopt and develop water accounting system and capacity at the country level. This is in supporting meeting the SDGs 2030 agenda and support the shift in water management into integrated water management in sustainably manner and allocated water to high productive sector but also support the water resources planning and policy development and inform water debates at the country and regional level. However, the many trials that currently in places by several donors and countries have proven the case of lacking understanding what water accounting system is and what are its key components and how can be designed and developed.

This paper, presented and described the main common challenges that reported and faced by many countries in developing and designing their water accounting system It presented the WARS-Water Accounting Reporting System framework with the attention to provide answering to these hindered questions and supporting the current activities by many countries. WARS provided a schematic structure of the water accounting system and simple processes that can guiding the country to go around the development of its tailored base water accounting system that fit for their purposes and answer their key priority questions. The paper also presented the proposed appropriate structure of the water accounting team or unit that can implement and lead the processes to design and develop water accounting that meet the country's priorities and answering the key questions raised from the local and contextual challenges. Further research needs to look at the implementation of WARS.

\section{References}

1. Elmahdi A, Abu Elnaga H (2019) The world is off track to achieve SDG 6 , only 10 years to harvest! What can MENA region do Smart Water
Magazines.

2. Ariyama J, Charles Batchelor C, Elmahdi A, Wahaj R, Vallee D (2019) Count and account water for agricultural sustainability and sustainable development in the NENA region'- World water Forum 2019.

3. Margat J, Babillot $P$ (1999) National water comptability in France: an instrument for analysing and managing. LA HOUILLE BLANCHE/ ${ }^{\circ}$ 3/4-1999.

4. FAO (2007) Modernizing irrigation management - the MASSCOTE approach, by D Renault, T Facon, R Wahaj. FAO 2007. IDP 63, p. 207.

5. FAO (2013) Multiple uses of water services in large irrigation systems: Auditing and planning modernization The MASSMUS Approach. FAO 2013. IDP 67, p. 199.

6. Batchelor C, Hoogeveen J, Faurès J, Peiser L (2017) Water accounting and auditing - A sourcebook. FAO, Rome.

7. Ariyama J, Boisramé GFS, Brand MR (2019) (forthcoming in June 2019). Water Budgets for the Delta Watershed: Putting Together the Many Disparate Pieces. San Francisco Estuary and Watershed Science $17(2)$.

8. Amgad Elmahdi (2019a) Road Maps for Water Accounting Designing and Institutionalizing for Sustainable Water Management in MENA Region. Int J Environ Sci Nat Res 22(4): 556092.

9. Collectif (1986) Les comptes du patrimoine naturel (INSEE. les collections de l'INSEE 137-138 C. n 535-536 : 552, Paris). Chap. 5. J. Margat, le compte des eaux continentales.

10. FAO (2017) Water accounting and auditing sourcebook. FAO Water Report 43.

11. Amgad Elmahdi (2019b) The role of water accounting in sustainable water resources management and SDGs Reporting" WFES Water Forum 2019, Abu Dhabi, pp. 14-17.

12. Elmahdi A, Parr E, Walters C, Vranes M (2017) Australian Country paper: Institutional Reform in Irrigation Sector for Sustainable Agricultural Water Management; ICID.

13. ICID (2019) Water Accounting as a Sustainable Agricultural Water Management Framework, 2019.

14. Commonwealth of Australia (Bureau of Meteorology) (2010) Improving water information program, annual report. 


(CC) This work is licensed under Creative
Commons Attribution 4.0 License
DOI: $10.19080 / I J E S N R .2020 .23 .556118$

Your next submission with Juniper Publishers will reach you the below assets

- Quality Editorial service

- Swift Peer Review

- Reprints availability

- E-prints Service

- Manuscript Podcast for convenient understanding

- Global attainment for your research

- Manuscript accessibility in different formats ( Pdf, E-pub, Full Text, Audio)

- Unceasing customer service

Track the below URL for one-step submission https://juniperpublishers.com/online-submission.php 